\title{
Policy Implication of the Awareness and Use of Biotechnology Products Among Farmers in Aboh-Mbaise Local Government Area of Imo State, Nigeria
}

\author{
${ }^{*}$ Matthews-Njoku, E. C and ${ }^{* *}$ O. M. Adesope \\ * Department of Agricultural Extension \\ Federal University of Technology, Owerri, Nigeria \\ ${ }^{* *}$ Department of Agricultural Economics and Extension, \\ University of Port Harcourt, Choba, PMB 5323, Port Harcourt, Nigeria \\ Email: dredna04@yahoo.co.uk
}

\begin{abstract}
The study investigated awareness of and extent of the use of biotechnology products among farmers in Aboh-Mbaise local government area of Imo State, Nigeria. Data for the study were collected with the aid of structured questionnaire from 60 randomly selected respondents in the study area. Data were analyzed using frequencies, percentages and mean scores. The study revealed that majority (88.3 percent) of the respondents are aware of the existence of biotechnology products and majority (76.7 percent) of the respondents use biotechnology products. It was observed that genetically modified cassava variety is the most used biotech product in the study area as it scored a mean of 3.25 followed by biotech maize and tree crops which scored means of 2.68 and 2.67 respectively. It was also revealed that genetically modified cassava varieties was the most available biotech product in the study area, and closely followed by biotech tree crops. In the same vein biotech cassava variety is the most used biotech product in the study area. Based on the findings of this study, the following recommendations are made: There is need for adequate and proper education of farmers about biotechnology and its relative advantages. Adequate extension policy on availability of genetically modified yam, cowpeas, sorghum, millet and vegetables will meet help to meet the needs of the farmers and other end users. It is only if they are available that they can be utilized.
\end{abstract}

\section{INTRODUCTION}

Food production is central to agricultural activities and this sustains man. Therefore, man in order to improve and sustain this all-important product has done a lot of things to increase and improve the production of food so as to meet his needs for it. Improvement in agriculture takes different forms and man has devised a lot of strategies and methods to improve agriculture and its productivity so as to meet the chains of unending needs of man. One of the ways in which man has made efforts to increase and improve food production is in the area of biotechnology generation. According to Swaminathan (2002) biotechnology is largely associated with genetic manipulation at the DNA. Genetically modified technology can be applied to some specific problems of agriculture, indicating the potential for benefits such as pest resistance, tolerance to biotic and abiotic stresses, efficient use of farmland, reduced environmental impact and improvement of productivity. 
The Green Revolution of the 1960s and 1970s, according to Chassy (2003), helped India and China and other Asian countries become agriculturally self-sufficient net exporters of food in the last three decades. The increased productivity has been accompanied by increases in personal income and stimulus of national economies.

Similarly, through application of new technology, agricultural productivity per hectare has doubled in most developed countries in the same timeframe. Although most of the researches and applications of biotechnology is in the developed countries, it is also said that interest and concentration has not been placed on this technology in developing countries (Penn, 2005). Onoja and Audu (2005) observed that given the potentials of biotechnology in poverty and hunger reduction, it is rather worrisome to note that Nigeria is not taking the lead and adequate initiatives in enunciating policies of biotechnology in Africa despite its acclaimed position as "the giant of Africa" and indeed her status as the most populous black country in the world.

The development of new high-productivity agricultural technologies resulted from investment in agricultural research performed in government laboratories, research universities and non-governmental institutes such as the Consultative Group on International Agricultural Research (CGIAR) centres scattered around the globe and the International Institute of Tropical Agriculture. Ukpabio (2004), however, noted that application of biotechnology in agricultural production in Nigeria is more prominent in crop production than in animal production. However, biotechnology is applied in various aspects of animal research (reproduction, breeding, nutrition processing and veterinary drugs) at the National Veterinary Research Institute (NVRI), Vom near Jos and the National Animal Production Research Institute (NAPRI), Shika, Zaria. Modern biotechnology techniques are currently being used in many areas such as food, agriculture, health care, forestry, environment, mineral, oil and gas recovery and industrial processes to develop new products and processes, and to modify existing ones (CBSS, 1998). The awareness about biotechnology is generally increasing, what is not certain is the level of utilization among farmers. This study therefore investigates awareness of and extent of use of biotechnology products among farmers in Aboh-Mbaise local government area of Imo State, Nigeria

\section{RESEARCH METHODOLOGY}

\section{Study area}

The study was carried out in Aboh-Mbaise local government area of Owerri Agricultural Zone of Imo state. It has a tropical climate and experience two distinct seasons, rainy and dry within a year. The rainy season in some years may be interrupted by a short dry spell of about one or two weeks around the month of August. The dry season lasts for about five months (November to March) accompanied by the cool harmattan wind which occurs around the months of December to February. The mean annual rainfall of Aboh-Mbaise LGA is between $2000 \mathrm{~mm}$ to $2500 \mathrm{~mm}$. The mean annual temperature is between $26^{\circ} \mathrm{C}$ and $28^{\circ} \mathrm{C}$, with mean daily maximum and minimum temperatures rarely below $27^{\circ} \mathrm{C}$ and $18^{\circ} \mathrm{C}$ respectively. Relative humidity is between $80-90$ percent occurring during the dry season and especially during the dry harmattan wind (FDLAR, 1985). 
Journal of Agricultural Extension

Vol. 12 (2) December, 2008

\section{Population and sample}

Aboh-Mbaise LGA has 10 extension circles covered by extension Agents. There are 130 Fadama users group (FUG) and 6 Fadama Community Associations (FCA). The people are predominantly farmers. Most of the farmers practice subsistence agriculture while few are into commercial farming. Crop production and animal husbandry are practiced. The crops produced include maize, cassava, yam, coco yam, fluted pumpkin, pepper, garden egg, etc. The animals reared include poultry, goat and sheep. The population of the study consists of the farmers in AbohMbaise local government area. Aboh-Mbaise L.G.A is made up of 11 communities which include Enyiogugu, Okwuato, Uvuru, Chokoneze, Amuzu, Mbutu, Lorji, NguruNweke, Nguru-Nwekwo, Nguru-Nweorie and Nguru-Nweafor.

Multi-stage random sampling technique was used to select the sample for the study. In the first stage, Five (5) communities/towns were randomly selected out of the 11 communities in Aboh-Mbaise L.G.A. The communities/towns selected include Enyigugu, Okuwato, Nguru-nweke, Mbutu and Uvuru. Secondly, fifteen villages were randomly selected from the 5 communities/towns. Then, thirdly 5 farmers were randomly selected from each of the 15 villages. Based on this, a total of 75 farmers were involved in the study, but data for only 60 respondents was used for analysis.

\section{Instrument for data collection}

A structured questionnaire was used for data collection. This was administered to 75 farmers involved in the study. However, a total of 60 copies of filled questionnaires were retrieved giving a responses rate of $80 \%$.

\section{Analysis of data} scores.

Data collected were analyzed using frequencies, percentages and mean

\section{RESULTS AND DISCUSSION}

\section{Awareness of Existence of Biotechnology Products}

Table 1 shows that 88.3 percent of the respondents were aware of the existence of biotechnology products in the study area, while $11.7 \%$ were not aware. This means that majority $88.3 \%$ of the respondents had knowledge of the existence of biotechnology products in the study area.

TABLE 1: Distribution of Respondents according to their Awareness of the Existence of Genetically Modified products in the area

\begin{tabular}{lcc}
\hline $\begin{array}{l}\text { Awareness of the existence of Genetically } \\
\text { modified products }\end{array}$ & Frequency & Percent \\
\hline Aware & 53 & 88.3 \\
Not aware & 7 & 11.7 \\
Use of Genetically modified products & & \\
Have used & 46 & 76.7 \\
Not used & 14 & 23.3 \\
\hline
\end{tabular}

Source: Field survey data, 2007 
The importance of awareness to utilization of a technology cannot be overemphasized. Adekoya and Oladele (2008) had found that awareness of Genetically Modified products was high while Oladele and Akinsorotan (2007) reported that awareness influenced perception towards Genetically Modified Organisms (GMOs)

About 76.7 percent of the respondents used Genetically modified products in the study area, while 23.3 percent of them do not use Genetically modified products. This may be attributed to the high level of awareness of existence of Genetically modified products by the respondents as revealed in table 1 .

\section{Genetically Modified Products Available}

TABLE 2: Distribution of Respondents According to the Genetically Modified Products available to them.

\section{Genetically Modified products Frequency Percent Ranking} available to respondents

\begin{tabular}{lccc}
\hline Cassava & 41 & 68.3 & 1 st \\
Maize & 29 & 48.3 & 3rd \\
Yam & 18 & 30 & 4 th \\
Vegetable & 5 & 8.3 & 5 th \\
Sorghum/millet & 0 & 0 & 6 th \\
Cowpea/Beans & 0 & 0 & 6 th \\
Tree crops & 30 & 50 & 2nd \\
\hline
\end{tabular}

Multiple responses recorded

Source: Field survey, 2007

Table 2 shows that $68.3 \%$ of the respondents had genetically modified cassava varieties available to them. The ranking of the products show that it is the most available Genetically modified product in the study area, $48.3 \%$ have Genetically Modified maize available to them, 30 percent had genetically modified yam varieties $8.3 \%$ has genetically modified vegetable species available to them, non of the respondents have biotech sorghum/millet and cowpea while 50 percent of the respondents had biotech tree crop available to them. This therefore suggests that genetically modified cassava and tree crop are the most available and 2nd most available biotech products to the respondents respectively while sorghum/millet and cowpea/beans are not available in the study area at all. 
Journal of Agricultural Extension

Vol. 12 (2) December, 2008

\section{Source of Genetically modified Products}

TABLE 3: Distribution of Respondents According to their Source of Genetically Modified Products

\begin{tabular}{|l|l|l|}
\hline $\begin{array}{l}\text { Source of Genetically Modified } \\
\text { products }\end{array}$ & Frequency & Percent \\
\hline Village extension agents & 17 & 28.3 \\
\hline Ministry of Agriculture in the L.G.A & 16 & 26.7 \\
\hline $\begin{array}{l}\text { Obtained from research centers } \\
\text { institution }\end{array}$ & 7 & 11.7 \\
\hline Bought from market & 15 & 25 \\
\hline Neighbors/friends & 5 & 8.3 \\
\hline Total & $\mathbf{6 0}$ & $\mathbf{1 0 0}$ \\
\hline
\end{tabular}

Source: Field survey data, 2007

Table 3 shows the distribution of respondents according to their source of Genetically modified products. From the table, $28.3 \%$ of the respondents obtain their Genetically modified products from Village Extension Agents, $26.7 \%$ said they obtain from the Ministry of Agriculture in the local government area, $11.7 \%$ have their source as research centers or institutions, $25 \%$ said they bought them from the market, while $8.3 \%$ said they bought from market while $8.3 \%$ say they obtain from their neighbours. The data obtained from the study suggests that majority $(55 \%)$ of the respondents have their source of Genetically modified products as the Village Extension Agents in the area and the Ministry of Agriculture in the L.G.A. This, therefore means that Extension Service in the study area and the Ministry of Agriculture in the L.G.A are fairly effective and useful in dissemination of genetically modified products to the area.

\section{CONCLUSION}

The importance of biotechnology to contemporary situation cannot be overestimated. This is bearing in mind the fact that there is an ever increasing population leaving more mouths to be fed from farm produce. This study has revealed that availability of genetically modified products influences utilization to a large extent and this has implication for agricultural production. The implication of this to extension is that extension will have to take the lead in proper dissemination of information about genetically modified products and educating farmers to adopt the genetically modified products for more farm output.

\section{RECOMMENDATIONS}

Based on the findings of this study, the following recommendations are made:

1. There is need for adequate information and proper education of farmers about genetically modified products and their relative advantages because some farmers are not aware of the relative advantages of using genetically modified products over their local varieties. 
2. There is need for both public and private investment into biotechnology research for the dissemination of biotechnology information.

3. The biotechnology products should be made readily available to farmers and at a relatively affordable price so as to be within the reach of poor farmers.

4. Extension should be adequately involved in communicating information biotechnology research as they understand farmer's needs and desires so as to develop that innovation that meets the needs of the farmers.

\section{References}

Adekoya, A.E. and O.I. Oladele (2008) Improving technology perception through information and education: A case of Biotechnology in Nigeria. Agricultural Journal, 3 (5), 414-417.

CBSS (1998) What is Biotechnology. Ontario Canada, Canadian Biotechnology Strategy Secretariat.

Chassy, B (2003) The role of Agricultural Biotechnology in World food aid. UrbanChampaign, University of Illinois Urbana-Champaign.

Oladele, O.I. and Akinsorotan, O.A. (2007) Effect of genetically modified organisms (GMOs) on health and environment in Southwestern Nigeria: Scientists' Perception. Journal of Agricultural Extension, Vol. 10, pp.60-70.

Onoja, A.O and Audu, S. I (2005) The potentials and constraints of biotechnology, adoption in poverty reduction in Nigeria. In: Production Agriculture and Technology. Journal of the Faculty of Agriculture, Nassarawa State University Lafia. Vol. 1, pg.26-36.

Penn, J.B (2005) Agricultural Biotechnology and the developing world. Washington D.C, United States Department of Agriculture (USDA).

Ukpabio, U.H (2004) Application of biotechnology in Ruminant nutrition. In: Issues in sustainable Agriculture in Nigeria.

Swaminathan, M.S (2002) Genetic engineering and food security. Ecological and livelihood issues 37-44. In: G.J. Persley and M.M. Lantin (eds) Agricultural biotechnology and the rural poor. Consultative group on International agricultural Research, Washington DC, USA. 